\title{
MiR-143 Regulates Milk Fat Synthesis by Targeting Smad3 in Bovine Mammary Epithelial Cells
}

\author{
Li Zhang, Zhang-Qing Wu, Yu-Juan Wang, Meng Wang and Wu-Cai Yang *
}

College of Animal Science and Technology, Northwest A\&F University, Xianyang 712100 Shaanxi, China; frankfrank4@163.com (L.Z.); w2452711225@126.com (Z.-Q.W.); 18792683933@163.com (Y.-J.W.);

wangmeng1001@nwafu.edu.cn (M.W.)

* Correspondence: yangwucai111@nwafu.edu.cn; Tel./Fax: +86-029-8709-1247

Received: 22 July 2020; Accepted: 15 August 2020; Published: 19 August 2020

Simple Summary: The fat content of milk is the main determinant of its nutritional value, and therefore the study of milk fat synthesis has often received a special focus in research. MicroRNAs (miRNAs) are short RNA sequences which have a crucial function in the synthesis of milk fat. miR-143 is one of the miRNAs closely related to lipid metabolism. In this study, the results showed that miR-143 significantly promoted lipid droplet formation and increased the level of intracellular triglyceride (TAG) via increasing the lipid synthesis related genes such as PPAR $\gamma$, FASN, SCD1, CEBP $\beta$, and SREBP1 by targeting Smad3. Herein, we constructed a miR-143-Smad3 regulatory network map, which revealed the interactions between miR-143 and Smad3 in milk fat synthesis. These findings provide an insight into understanding the theoretical basis of the genes and can thus be applied in the molecular breeding of dairy cows.

\begin{abstract}
Milk fat is the main nutritional component of milk and is also an important indicator for evaluating milk quality. Substantial evidence has implicated miRNAs in the synthesis of milk fat. miR-143 is one of the miRNAs closely related to lipid metabolism. Herein, miR-143 upregulation remarkably promoted the production of lipid droplets and increased the level of intracellular triglyceride (TAG). Meanwhile, miR-143 suppression overtly repressed TAG synthesis and lipid droplet accumulation in bovine mammary epithelial cells (BMECs). At the same time, miR-143 significantly upregulated the genes associated with lipid synthesis, including PPAR $\gamma$, SCD1, CEBP $\beta$, and SREBP1. To examine the regulatory mechanism of miR-143 in milk fat synthesis, Smad3 was predicted as a new potential miR-143 target gene by TargetScan. Further studies found that miR-143 expression was inversely related to the levels of Smad3 mRNA and protein. Furthermore, luciferase reporter assays confirmed Smad3 to be a miR-143 direct target. Moreover, Smad3 gene silencing significantly increased intracellular TAG level in BMECs. These findings revealed that miR-143 promotes the TAG synthesis in BMECs via increasing the lipid synthesis related gens expression by targeting Smad3. The results of this study can be exploited in devising novel approaches for improving the nutritional value of milk in dairy cows.
\end{abstract}

Keywords: mammary epithelial cells; miR-143; triglyceride; Smad3

\section{Introduction}

Cow milk is a natural food with high nutritional benefits and is therefore considered as basic food in many diets. Milk fat is the main determinant of its nutritional value, and as such it is usually applied to indicate milk quality [1,2], and therefore its synthesis process has been widely studied [3-5]. Milk fat synthesis is influenced by several factors, such as heredity, hormone, physiology, environment, 
and nutrition [6-8], but the understanding of the regulation mechanism of milk fat synthesis is still minimal.

MicroRNAs (miRNAs) are short RNA sequences that inhibit mRNA translation and protein synthesis by binding to a mRNA of the target [9]. Recent evidence shows that miRNAs play a crucial function in different biological processes, including cell differentiation, migration, proliferation, apoptosis, and survival [10]. Furthermore, miRNAs play an essential function in the synthesis of milk fat [8]. Shen et al. [6] identified 97 differential expressed miRNAs in the mammary epithelial cells of high-fat and low-fat dairy cows. Further studies found that miR-103, miR-17-5p, and miR-148a enhanced milk fat synthesis by facilitating lipid droplet formation and accumulation of triglycerides [11,12], while miR-181a, mir-34b, and mir-130a inhibit the synthesis of milk fat by downregulating the expression of key genes of lipid synthesis $[8,13]$.

miR-143 is one of the miRNAs closely linked to lipid metabolism [14], which regulates adipocyte differentiation and triglycerides synthesis by modulating the expression of target genes [15]. Levels of miR-143 have been shown to be higher in differentiating adipocytes. Moreover, miR-143 inhibition successfully suppresses adipocyte differentiation [16]. Meantime, miR-143 overexpression promotes fat formation via accelerating lipid droplet aggregation and inhibiting the synthesis of glycerol and free fatty acids in adipocytes $[17,18]$. Furthermore, Shen et al. [6] found that miR-143 expression in mammary epithelial cells of the high milk fat group was overtly higher relative to that of the low milk fat group [6]. Given this, we speculated that miR-143 might participate in the milk fat synthesis process in bovine mammary epithelial cells (BMECs).

\section{Materials and Methods}

\subsection{Cell Culture and Transfection}

BMECs were extracted from mammary gland tissue of Holstein cows in mid lactation following published protocols [4]. The BMECs were cultured in basal DMEM/F12 medium comprising fetal bovine serum (10\%), 100 units $/ \mathrm{mL}$ penicillin, $100 \mu \mathrm{g} / \mathrm{mL}$ streptomycin, $5 \mu \mathrm{g} / \mathrm{mL}$ bovine insulin, and $1 \mu \mathrm{g} / \mathrm{mL}$ hydrocortisone in $3761^{\circ} \mathrm{C}$ in a humidified atmosphere with $5 \% \mathrm{CO}_{2}$. For lactogenesis induction, BMECs were grown for $48 \mathrm{~h}$ in an induction medium composed of basal medium supplemented with $2 \mu \mathrm{g} / \mathrm{mL}$ bovine prolactin (Millipore, Sigma) before conducting the initial experiments. Subsequently, some cells were transfected with a miR-143 mimic $(50 \mathrm{nM})$, a miR-143 inhibitor (200 nM), si-Smad3 (100nM), and the corresponding negative controls (Songon Biotech Co., Ltd., Shanghai, China) as per the manufacturer's protocol. The sequences for si-Smad3 is as follows: Sense $5^{\prime}$-GCGUGAAUCCCUACCACUATT- $3^{\prime}$ and antisense $5^{\prime}$-UAGUGGUAGG GAUUCACGCTT-3'. Unless otherwise mentioned, all the reagents used in this stage were purchased from ThermoFisher Scientific, Shanghai, China.

\subsection{Gene Expression Assay}

TRIzol reagent (Sigma, Louis, MO, USA) was utilized in the isolation of total RNA as per the instructions of the manufacturer. The quality of total RNA was checked via a NanoDrop 1000 (ThermoFisher scientific, Shanghai, China). The OD260/280 value for all RNA samples was from 1.9 to 2.0, and the OD260/230 value was approximately 2.0. To synthesize cDNA, we employed a high-capacity cDNA reverse transcription kit (Takara, Dalian, China) for mRNA expression assay and PrimeScript miRNA RT-PCR kit (Tiangen, Beijing, China) for analyzing miRNA expression. The internal control used to assess mRNA expression was the UXT gene [19], whereas, for miRNA expression, we utilized the U6 gene [20]. Real-time PCR primers (Table 1) were designed and synthesized by TSINGKE Biological Technology (Xi'an, China). The qRT-PCR was carried out using SYBR Premix Ex Taq II (Takara, Dalian, China) together with miRcute miRNA qPCR Detection Kit (Tiangen, Beijing, China). The reaction was carried out on a 7500 Real-Time PCR system (Applied Biosystems Inc., Foster City, CA, USA). The $2-\Delta \Delta \mathrm{Ct}$ method was applied in the calculation of relative gene expression [21]. 
Table 1. Sequence of primers for mRNA and miRNA quantitative real-time PCR.

\begin{tabular}{|c|c|c|}
\hline Genes & Primer Sequence $\left(5^{\prime}-3^{\prime}\right)$ & Annealing Temperature $\left({ }^{\circ} \mathrm{C}\right)$ \\
\hline UXT & $\begin{array}{l}\text { F:TAGCCACCCTCAAGTATGTTCG } \\
\text { R:CGAGGTAGGAGGACAGGAGT }\end{array}$ & $61^{\circ} \mathrm{C}$ \\
\hline PPAR $\gamma$ & $\begin{array}{c}\text { F:AAAGGAGAGCCTGAACTTGGAG } \\
\text { R:TCTGAACTGTGCTGTGGCAA }\end{array}$ & $61{ }^{\circ} \mathrm{C}$ \\
\hline FASN & $\begin{array}{l}\text { F:CCCTGAATGTGAGGCAGTGTG } \\
\text { R:TTAGCTGTGGTGAGGAGCCA }\end{array}$ & $61^{\circ} \mathrm{C}$ \\
\hline СЕВР $\beta$ & $\begin{array}{l}\text { F:TGGTGAATAGTGCTGCCCAT } \\
\text { R:GGTGGTAGTTGTGGAAGCCC }\end{array}$ & $61{ }^{\circ} \mathrm{C}$ \\
\hline SCD1 & $\begin{array}{l}\text { F:ACATTGATCCCCACCTGCAA } \\
\text { R:AAACGTCATTCTGGAACGGC }\end{array}$ & $61{ }^{\circ} \mathrm{C}$ \\
\hline SREBP1 & $\begin{array}{l}\text { F:CAA TGTGTGAGAAGGCCAGT } \\
\text { R:ACAAGGAGCAGGTCACACAG }\end{array}$ & $61^{\circ} \mathrm{C}$ \\
\hline Smad3 & $\begin{array}{l}\text { F: GAGTTGAAGCGAAGTTTGGGC } \\
\text { R: CTCTTGACTGCCTTCTCGCA }\end{array}$ & $61^{\circ} \mathrm{C}$ \\
\hline U6 & $\begin{array}{l}\text { F:TAGCCACCCTCAAGTATGTTCG } \\
\text { R:CGAGGTAGGAGGACAGGAGT }\end{array}$ & $61^{\circ} \mathrm{C}$ \\
\hline miR-143 & GCTCGATGTCACGAAGTAGAGT & $61{ }^{\circ} \mathrm{C}$ \\
\hline
\end{tabular}

\subsection{Oil Red O Staining and Triglyceride Assay}

BMECs were rinsed thrice in phosphate buffered saline (PBS, including $\mathrm{KCl} 0.02 \%, \mathrm{NaCl} 0.8 \%$, $\mathrm{KH}_{2} \mathrm{PO}_{4} \quad 0.02 \%$ and $\mathrm{Na}_{2} \mathrm{HPO}_{4} 0.29 \%$ in deionized distill water), then fixed for $40 \mathrm{~min}$ in $10 \%$ paraformaldehyde (1ml PBS, $0.5 \mu \mathrm{L} 10 \mathrm{~N} \mathrm{NaOH}$, and $0.1 \mathrm{~g}$ paraformaldehyde) at $4{ }^{\circ} \mathrm{C}$. After washing in PBS, the cells were stained with $5 \%$ Oil Red O in isopropanol for $40 \mathrm{~min}$. Next, the cells were cleaned by PBS, and the lipid droplets were microscopically examined. A cell/tissue triglyceride assay kit (Applygen Technologies, Beijing, China) was used to measure the amount of intracellular TAG, as per the manufacturer's recommended protocol.

\subsection{Luciferase Reporter Assay}

MiR-143 target genes and miRNA binding sites were identified using TargetScan [22]. The mature sequence of miR-143 was obtained from the miRBase Sequence Database (miRDB, http://www.mirbase. org). Reporter constructs for luciferase were generated through the synthesis of 3'-UTR wild-type (WT) and mutation type (MUT) of Smad3 sequences by ShengGong (Songon Biotech Co., Ltd., Shanghai, China) and cloned into the psiCHECK-2 vector (Promega, Madison, WI, USA) at the NotI and XhoI restriction sites (Promega, Madison, WI, USA). BMECs were grown in 12-well plates and transfected at $70 \%$ confluence using Lipofectamine 3000 reagent (Invitrogen, Waltham, MA, USA). About $0.16 \mu \mathrm{g}$ of MUT vector/Smad-3' UTR WT was co-transfected with 5 pmol miR-143 mimics/a negative control into BMECs. Luciferase reporter assay system (Promega, Madison, WI, USA) was utilized to assess the luciferase activity following $48 \mathrm{~h}$ of transfection.

\subsection{Western Blot Assay}

BMECs were collected using $0.25 \%$ trypsin (Solarbio, Beijing, China) and lysed in RIPA buffer (Solarbio, Beijing, China) containing 1\% PMSF (Pierce, Rockford, IL, USA). Western blot was carried out as described previously [5]. Primary antibodies against $\beta$-actin (mAbcam 8226) (1:2000, Abcam), Smad3 (C679H) (1:1000, Cell Signaling Technology), and HRP goat Anti-Rabbit IgG secondary antibody (ab97051) (1:2000, Abcam) were used. Chemiluminescent ECL Western blot system (Pierce, Rockford, IL, USA) was utilized in signal detection. 


\subsection{Statistical Analysis}

The analyses were completed using GraphPad Prism 6.01 software. Data were presented as the mean \pm SD. Each experiment contained at least three replicates. Student's $t$-test was used for pairwise comparisons. Statistical significance was detected at $p<0.05, p<0.01$, and $p<0.001$.

\section{Results}

\subsection{MiR-143 Promotes Triglyceride and Lipid Droplet Accumulation in BMECs}

The efficiency of miRNA mimic and inhibitor transfection were confirmed by RT-PCR. The results indicated that miR-143 mimic markedly increased miR-143 expression (Figure 1A), whereas miR-143 inhibitor considerably inhibited miR-143 expression (Figure 2A). To reveal the miR-143 role in lipid metabolism, we examined the levels of triglyceride and the accumulation of lipid drop following the overexpression or silencing of miR-143. We found that miR-143 mimic significantly increased TAG levels relative to the control group (Figure 1B) and led to a marked rise in the number of lipid droplets (Figure 1C). On the contrary, the number of lipid droplets and the level of TAG decreased significantly when miR-143 was inhibited (Figure 2B,C). Collectively, our findings indicate that miR-143 has played a promotive role in milk fat synthesis.
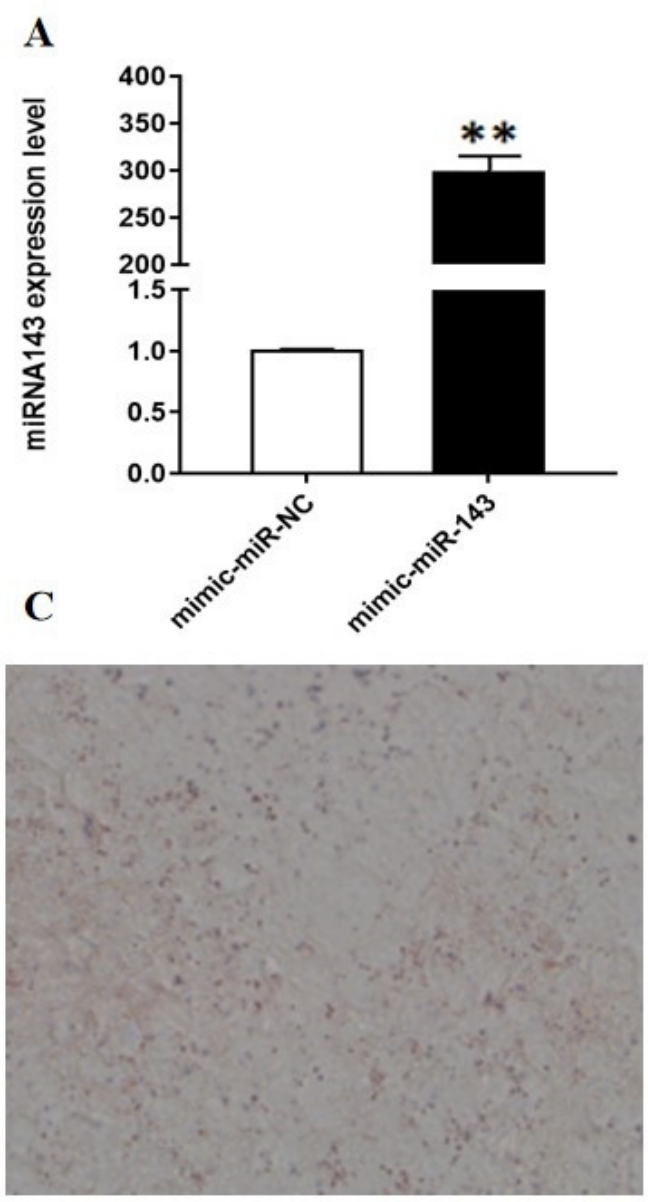

mimic-miR-143
$\mathbf{B}$
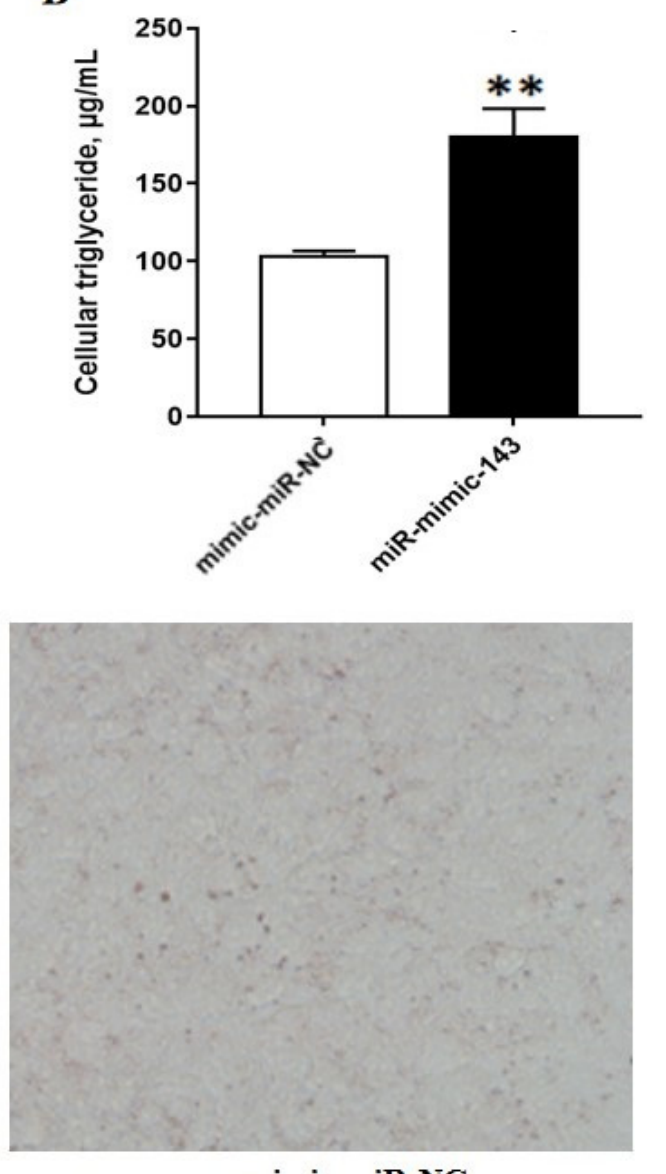

mimic-miR-NC

Figure 1. Effects of miR-143 mimic on milk fat synthesis. (A) miR-143 expression following miR-143 mimic treatment; (B) triglyceride levels in bovine mammary epithelial cells (BMECs) after treatment with the miR-143 mimic; (C) alteration in the number of lipid droplet in BMECs following miR-143 mimic treatment. ${ }^{* *} p<0.01$. 

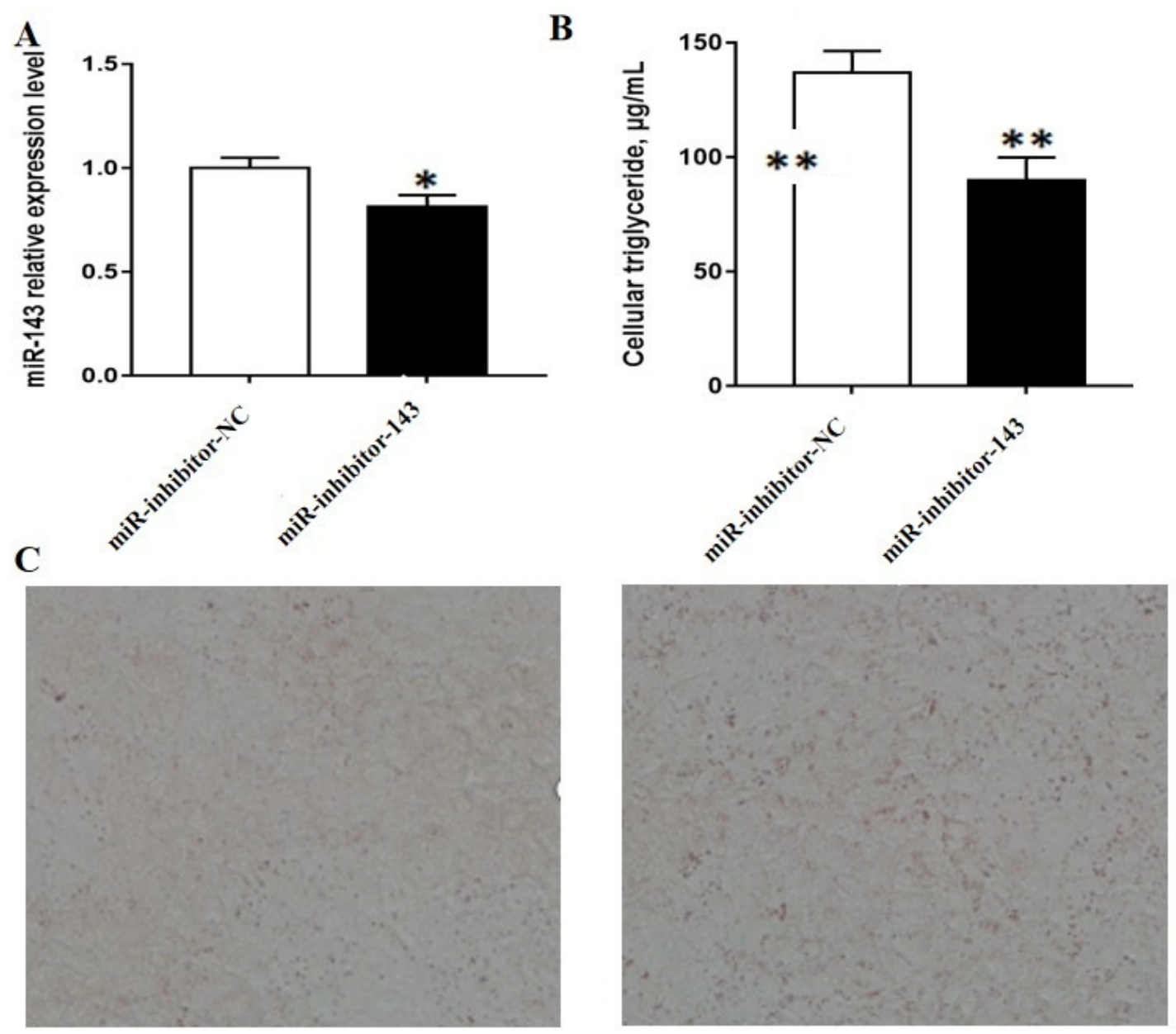

miR-143-inhibitor

miR-inhibitor-NC

Figure 2. Effects of miR-143 inhibitor on milk fat synthesis. (A) miR-143 expression following miR-143 inhibitor treatment; (B) triglyceride levels in BMECs after treatment with the miR-143 inhibitor; (C) alterations in the number of lipid droplet in BMECs after miR-143 inhibitor treatment $*<0.05$; ** $p<0.01$.

\subsection{MiR-143 Regulates Lipid Metabolism-Related Genes in BMECs}

The genes previously identified to be associated with lipid metabolism were quantified via real-time PCR after transfection. miR-143 overexpression significantly upregulated lipid synthesis-associated genes such as PPAR $\gamma(p=0.0001), \operatorname{SCD} 1(p=0.0120), \operatorname{SREBP} 1(p=0.008), \operatorname{CEBP} \beta(p=0.0199)$, and FASN $(p=0.1199)$ (Figure 3A). However, we found that miR-143 inhibitor markedly down-regulated the expression of PPAR $\gamma(p=0.0193)$, SREBP1 $(p=0.0463)$, FASN $(p=0.0193)$, and SCD1 $(p=0.0279)$ relative to the control group (Figure $3 \mathrm{~B}$ ). 

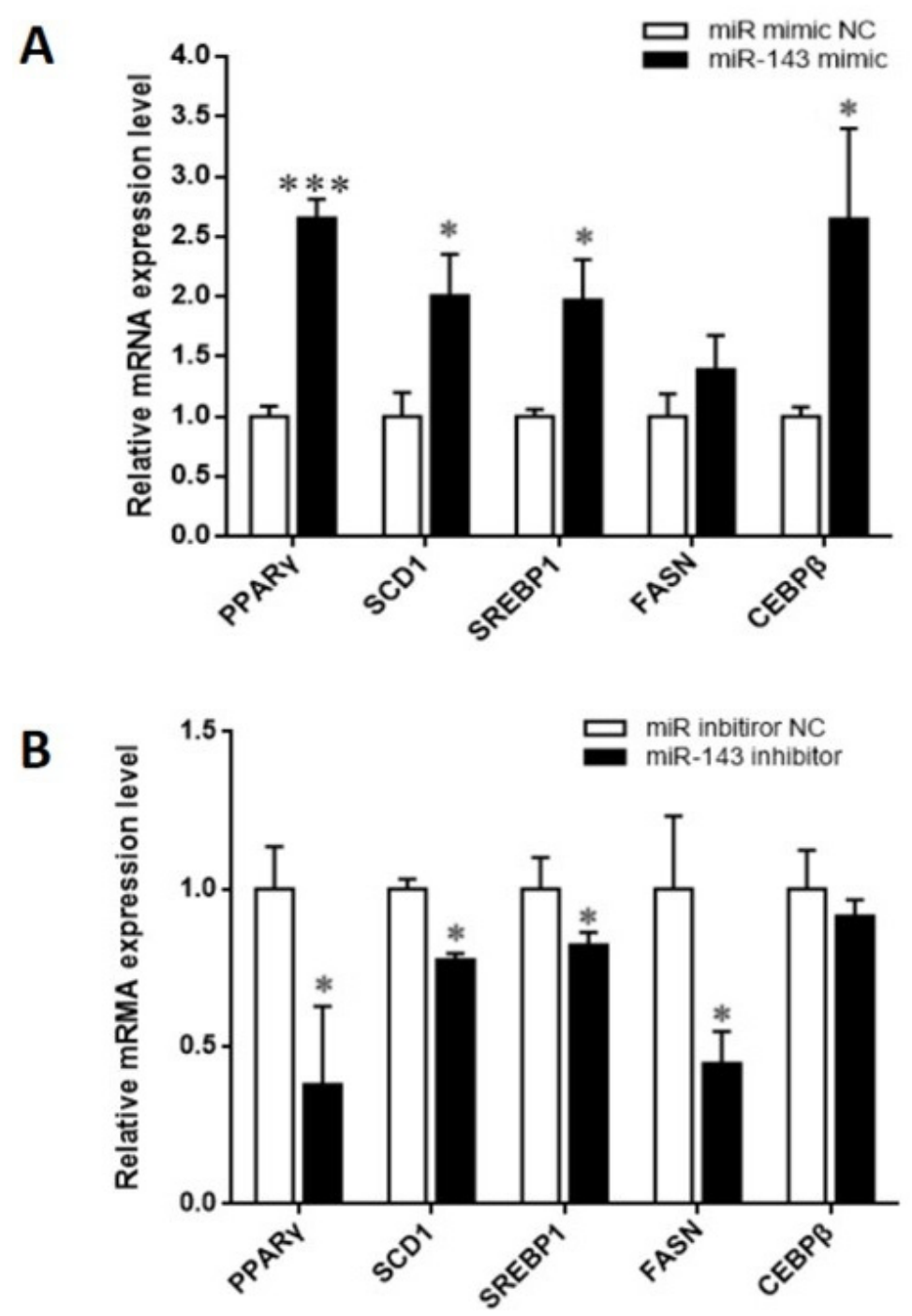

Figure 3. Effects of miR-143 on the expression of the genes related to lipid metabolism. (A) BMECs were transfected with miR-143 mimic; (B) BMECs were transfected with miR-143 inhibitor. ${ }^{*} p<0.05$, and ${ }^{* * *} p<0.001$.

\subsection{Smad3 is a Target Gene of miR-143}

As Figure 3A shows, miR-143 mimic significantly down-regulated the Smad3 gene. In contrast, miR-143 inhibitor remarkably enhanced Smad3 gene expression $(p<0.01)$ (Figure 4). In parallel, Western blot assay revealed that the levels of Smad3 protein in miR-143 mimic and inhibitor transfection groups were the same as that of the mRNA expression response (Figure 4).

In addition to the result projected by TargetScan, the Smad3 gene could be the miR-143 target gene (Figure 5A). So, the luciferase reporter system was employed to confirm whether the Smad3 gene was the target gene of miR-143. The result showed that the Smad3-3'UTR-WT group is significantly different from NC and Smad3-3'UTR-MUT (Figure 5B). Relative to the negative control group, miR-143 mimic substantially reduced the normalized luciferase activity by $23.4 \%(p=0.042)$ (Figure 5B), whereas these repressions were completely abolished by the Smad-3'UTR MUT (Figure 5B). 

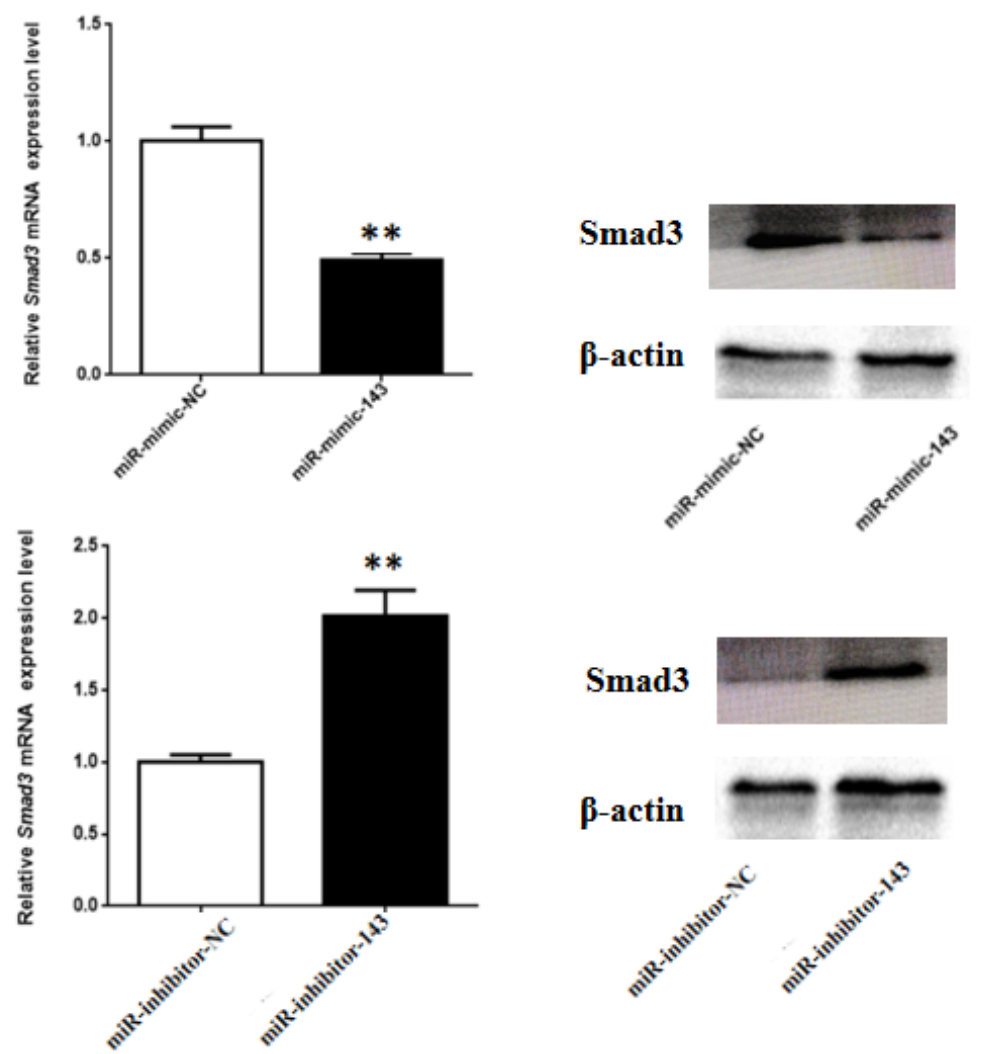

Figure 4. Impact of miR-143 on the Smad3 mRNA and protein expression. ${ }^{* *} p<0.01$.

A

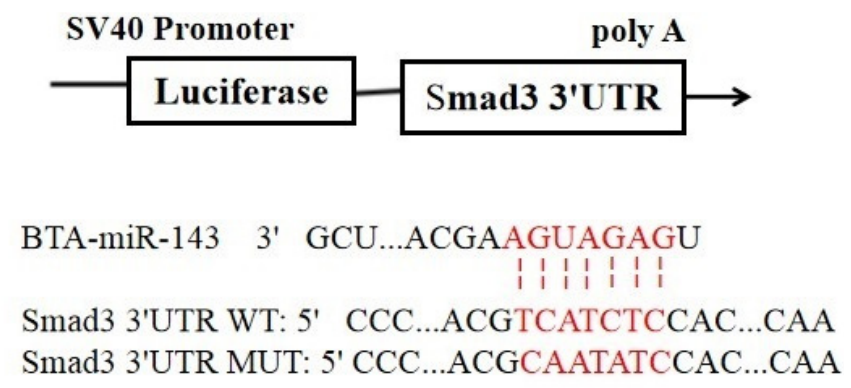

B

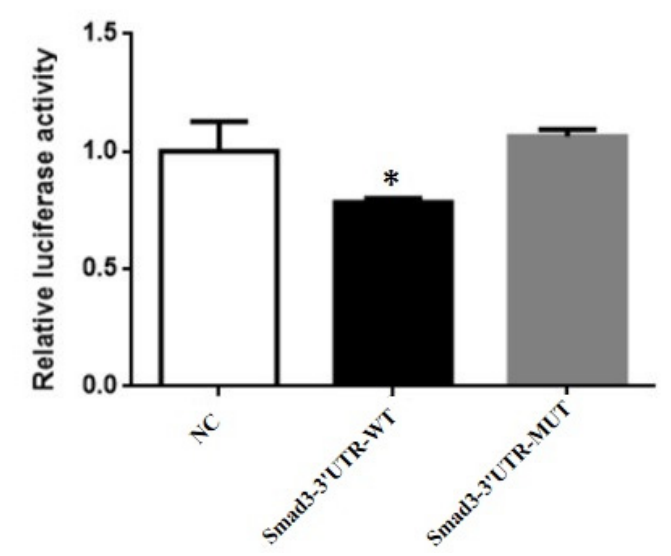

Figure 5. (A) Sequence alignment of miR-143 and the $3^{\prime}$-untranslated region (UTR) of Smad3 based on the TargetScan and miRDB algorithms; (B) changes in luciferase activity after the BMECs were co-transfected with miR-143 mimics and a luciferase reporter with a fragment of the Smad3 $3^{\prime}$-UTR harboring either the miR-143 binding site (Smad3-3'UTR-WT) or a mutant (Smad3-3'UTR-MUT). * $p<0.05$. SV40 = Simian virus 40; poly $\mathrm{A}=$ polyadenylic acid; BTA = Bos taurus. 


\section{4. siRNA-Smad3 Promotes Triglyceride Accumulation}

To reveal the role of Smad3 on lipid metabolism in BMECs, Smad3 silencing assay was conducted with specific siRNA. The optimal siRNA concentration for transfection in BMECs was determined to be $100 \mathrm{nM}$ and with high knock down efficiency (Figure 6A,B), and smad3 gene silencing significantly increased TAG level in BMECs (Figure 6C).

A

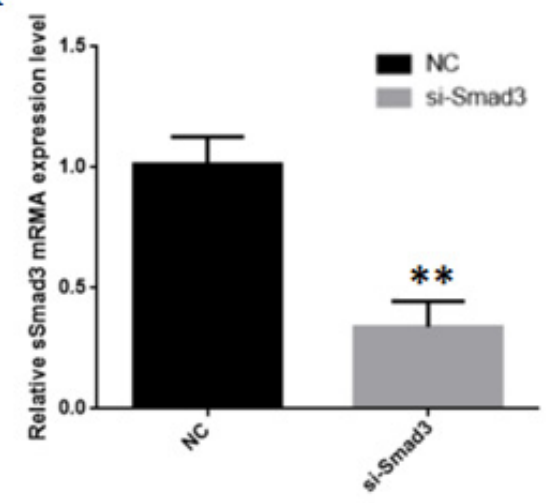

$\mathbf{B}$
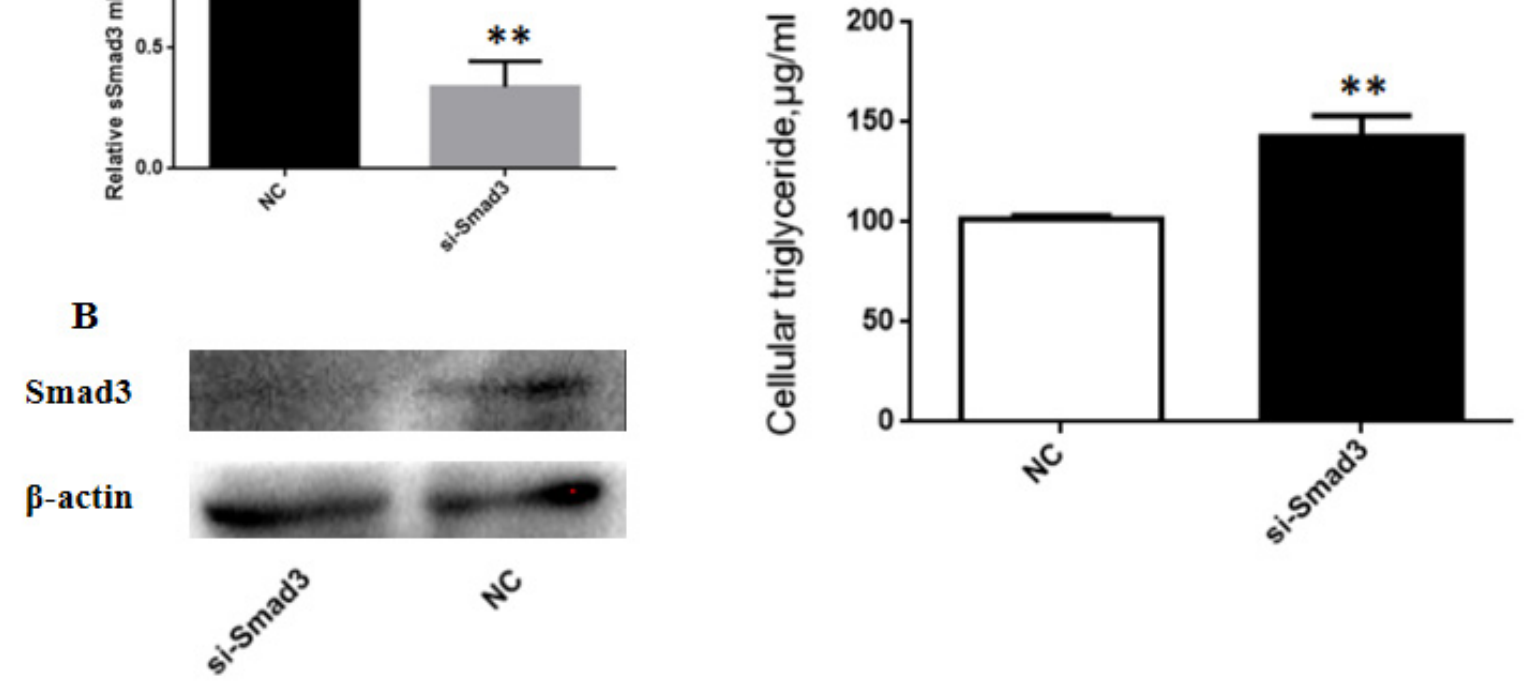

Figure 6. Effects of Smad3 on milk fat synthesis. (A,B) Comparative expression of Smad3 mRNA and protein in BMECs transfected with the si-Smad3 and negative control for $48 \mathrm{~h}$. (C) Triglyceride levels in BMECs after treatment with the si-Smad3. ${ }^{* *} p<0.01$.

\section{Discussion}

Growing evidence has revealed that miRNAs play a crucial function in the milk fat synthesis [8,23-25]. miR-143 is one of the miRNAs closely related to lipid metabolism [14]; previous studies indicated that miR-143 participates in the differentiation of adipocytes, as well as triglyceride synthesis [15-18]. Furthermore, miR-143 was found to be differentially expressed in BMECs of high milk fat group and low milk fat group [6]. So, we centered on the function of miR-143 in milk fat synthesis.

Herein, we found that miR-143 significantly promoted the triglyceride and lipid droplet accumulation in BMECs, which is consistent with previous work showing that miR-143 stimulates adipogenesis in mice and humans [18]. Furthermore, miR-143 increased the expression of PPAR $\gamma$, SCD1, SREBP1, CEBP $\beta$, and FASN. PPAR $\gamma$, SREBP1, and C/EBP $\beta$ are key positive regulators of lipid accumulation and have been found to be significantly positively correlated with TAG content in BMECs and GMECs [26,27]. SCD1 is a lipogenic enzyme that regulates membrane lipid homeostasis and has been recognized as having large effects on milk fat composition [28]. FASN catalyzes fatty acid synthesis, and its expression is directly related to the occurrence of several milk traits, such as milk fat content and overall fatty acid composition [29]. Therefore, our results indicate that miR-143 might promote milk fat synthesis by affecting the expression of the key regulators of lipid accumulation in BMECs.

miRNAs can regulate multiple target genes, and exert their biological functions by different target genes in different cell types or in different cell states of the same cell type [30,31]. Chen et al. [32] and Kim et al. [33] revealed that miR-143 promotes adipogenesis by interacting with MAP2K5 and Pre-f-1 
in adipocytes. Zhao et al. [34] found that miR-143 regulates the apoptosis and proliferative abilities of cervical cancer cells by interacting with HIF- $1 \alpha$. Herein, we verified that miR-143 targets Smad3 in BMEC using three different assays. Being an intracellular protein, Smad3 promotes TGF- $\beta$ signal propagation to the nucleus from the cell membrane [35]. Yadav et al. [36] found that inhibition of Smad3 expression protects against obesity during high-fat feeding in vivo studies. Then in vitro experiments demonstrated that Smad3 mediates inhibition of adipocyte differentiation by TGF- $\beta$ via inhibiting the expression of several adipocyte marker genes, including C/EBPs, PPAR $\gamma$, and leptin [37-39]. Our results show that $\mathrm{Smad} 3$ gene silencing significantly increased the intracellular TAG level. So, we speculate that miR-143 promotes the formation of lipid droplet and TAG synthesis in BMECs via upregulation of the genes linked to lipid synthesis, like PPAR $\gamma$, FASN, SCD1, CEBP $\beta$, and SREBP1 by targeting Smad3.

\section{Conclusions}

Our results show that miR-143 participates in TAG synthesis in BMECs. Moreover, the results indicate that the miR-143-TGF- $\beta / \mathrm{Smad} 3$ axis might be vital for milk fat synthesis in BMECs. These results may assist in the development of unique strategies for improving beneficial milk components in dairy cows.

Author Contributions: Designed the experiments, W.-C.Y.; conducted the experimental work, L.Z., Y.-J.W., and M.W.; conducted the data analysis, L.Z. and W.-C.Y.; wrote the paper, L.Z. and W.-C.Y.; revised the paper, L.Z., Y.-J.W. and M.W.; data curation, Z.-Q.W. All authors have read and agreed to the published version of the manuscript.

Funding: Research supported by the National Natural Science Foundation of China (No. 32402046).

Conflicts of Interest: The authors declare no conflict of interest.

\section{References}

1. Jensen, R.G.; Ferris, A.M.; Lammi-Keefe, C.J. The Composition of Milk Fat1. J. Dairy Sci. 1991, 74, 3228-3243. [CrossRef]

2. Li, D.; Xie, X.; Wang, J.; Bian, Y.; Li, Q.; Gao, X.; Wang, C. MiR-486 regulates lactation and targets the PTEN gene in cow mammary glands. PLoS ONE 2015, 10, e118284. [CrossRef] [PubMed]

3. Gengler, N.; Soyeurt, H.; Dehareng, F.; Bastin, C.; Colinet, F.; Hammami, H.; Vanrobays, M.L.; Lainé, A.; Vanderick, S.; Grelet, C.; et al. Capitalizing on fine milk composition for breeding and management of dairy cows1. J. Dairy Sci. 2016, 99, 4071-4079. [CrossRef]

4. Hou, X.; Lin, L.; Xing, W.; Yang, Y.; Duan, X.; Li, Q.; Gao, X.; Lin, Y. Spleen tyrosine kinase regulates mammary epithelial cell proliferation in mammary glands of dairy cows. J. Dairy Sci. 2016, 99, 3858-3868. [CrossRef] [PubMed]

5. Wang, Y.; Guo, W.; Xu, H.; Tang, K.; Zan, L.; Yang, W. Melatonin suppresses milk fat synthesis by inhibiting the mTOR signaling pathway via the MT1 receptor in bovine mammary epithelial cells. J. Pineal Res. 2019, 67, e12593. [CrossRef]

6. Shen, B.; Zhang, L.; Lian, C.; Lu, C.; Zhang, Y.; Pan, Q.; Yang, R.; Zhao, Z. Deep Sequencing and Screening of Differentially Expressed MicroRNAs Related to Milk Fat Metabolism in Bovine Primary Mammary Epithelial Cells. Int. J. Mol. Sci. 2016, 17, 200. [CrossRef]

7. Niu, M.; Harvatine, K.J. The effects of feeding a partial mixed ration plus a top-dress before feeding on milk production and the daily rhythm of feed intake and plasma hormones and metabolites in dairy cows. J. Dairy Sci. 2018, 101, 164-171. [CrossRef]

8. Wang, Y.; Guo, W.; Tang, K.; Wang, Y.; Zan, L.; Yang, W. Bta-miR-34b regulates milk fat biosynthesis by targeting mRNA decapping enzyme 1A (DCP1A) in cultured bovine mammary epithelial cells1. J. Anim. Sci. 2019, 97, 3823-3831. [CrossRef]

9. Bartel, D.P. MicroRNAs: Target recognition and regulatory functions. Cell 2009, 136, 215-233. [CrossRef]

10. Lu, T.X.; Rothenberg, M.E. MicroRNA. J. Allergy Clin. Immunol. 2018, 141, 1202-1207. [CrossRef]

11. Lin, X.; Luo, J.; Zhang, L.; Wang, W.; Gou, D. MiR-103 controls milk fat accumulation in goat (Capra hircus) mammary gland during lactation. PLoS ONE 2013, 8, e79258. [CrossRef] [PubMed] 
12. Chen, Z.; Luo, J.; Sun, S.; Cao, D.; Shi, H.; Loor, J.J. miR-148a and miR-17-5p synergistically regulate milk TAG synthesis via PPARGC1A and PPARA in goat mammary epithelial cells. RNA Biol. 2017, 14, 326-338. [CrossRef] [PubMed]

13. Lian, S.; Guo, J.R.; Nan, X.M.; Ma, L.; Loor, J.J.; Bu, D.P. MicroRNA Bta-miR-181a regulates the biosynthesis of bovine milk fat by targeting ACSL1. J. Dairy Sci. 2016, 99, 3916-3924. [CrossRef] [PubMed]

14. McGregor, R.A.; Choi, M.S. MicroRNAs in the regulation of adipogenesis and obesity. Curr. Mol. Med. 2011, 11, 304-316. [CrossRef]

15. Engin, A.B. MicroRNA and Adipogenesis. In Obesity and Lipotoxicity; Engin, A.B., Engin, A., Eds.; Springer International Publishing: Cham, Switzerland, 2017; pp. 489-509.

16. Esau, C.; Kang, X.; Peralta, E.; Hanson, E.; Marcusson, E.G.; Ravichandran, L.V.; Sun, Y.; Koo, S.; Perera, R.J.; Jain, R.; et al. MicroRNA-143 Regulates Adipocyte Differentiation. J. Biol. Chem. 2004, 279, 52361-52365. [CrossRef]

17. Romao, J.M.; Jin, W.; Dodson, M.V.; Hausman, G.J.; Moore, S.S.; Guan, L.L. MicroRNA regulation in mammalian adipogenesis. Exp. Biol. Med. 2011, 236, 997-1004. [CrossRef]

18. Bae, I.; Park, P.J.; Lee, J.H.; Cho, E.; Lee, T.R.; Kim, S.H. PPAR $\gamma$-mediated G-protein coupled receptor 120 signaling pathway promotes transcriptional activation of miR-143 in adipocytes. Gene 2017, 626, 64-69. [CrossRef]

19. Kadegowda, A.K.; Bionaz, M.; Piperova, L.S.; Erdman, R.A.; Loor, J.J. Peroxisome proliferator-activated receptor-gamma activation and long-chain fatty acids alter lipogenic gene networks in bovine mammary epithelial cells to various extents. J. Dairy Sci. 2009, 92, 4276-4289. [CrossRef]

20. Wang, M.; Moisá, S.; Khan, M.J.; Wang, J.; Bu, D.; Loor, J.J. MicroRNA expression patterns in the bovine mammary gland are affected by stage of lactation. J. Dairy Sci. 2012, 95, 6529-6535. [CrossRef]

21. Cash, J.L.; Hart, R.; Russ, A.; Dixon, J.P.; Colledge, W.H.; Doran, J.; Hendrick, A.G.; Carlton, M.B.; Greaves, D.R. Synthetic chemerin-derived peptides suppress inflammation through chemr23. J. Exp. Med. 2008, 205, 767-775. [CrossRef]

22. Agarwal, V.; Bell, G.W.; Nam, J.W.; Bartel, D.P. Predicting effective microRNA target sites in mammalian mRNAs. Elife 2015, 4, e05005. [CrossRef] [PubMed]

23. Chen, Z.; Chu, S.F.; Wang, X.L.; Sun, Y.J.; Xu, T.L.; Mao, Y.J.; Loor, J.J.; Yang, Z.P. MiR-16a Regulates Milk Fat Metabolism by Targeting Large Tumor Suppressor Kinase 1 (LATS1) in Bovine Mammary Epithelial Cells. J. Agric. Food Chem. 2019, 67, 11167-11178. [CrossRef]

24. Chen, Z.; Chu, S.F.; Wang, X.L.; Fan, Y.L.; Zhan, T.Y.; Adam, A.; Arbab, I.; Li, M.X.; Zhang, H.M.; Mao, Y.J.; et al. MicroRNA-106b Regulates Milk Fat Metabolism via ATP Binding Cassette Subfamily A Member 1 (ABCA1) in Bovine Mammary Epithelial Cells. J. Agric. Food Chem. 2019, 67, 3981-3990. [CrossRef] [PubMed]

25. Zhang, M.Q.; Gao, J.L.; Liao, X.D.; Huang, T.H.; Zhang, M.N.; Wang, M.Q.; Tian, Y.; Bai, J.; Zhou, C.H. miR-454 regulates triglyceride synthesis in bovine mammary epithelial cells by targeting PPAR- $\gamma$. Gene 2019, 691, 1-7. [CrossRef]

26. Liu, L.; Lin, Y.; Liu, L.; Wang, L.; Bian, Y.; Gao, X.; Li, Q. Regulation of peroxisome proliferator-activated receptor gamma on milk fat synthesis in dairy cow mammary epithelial cells. In Vitro Cell. Dev. Biol. Anim. 2016, 52, 1044-1059. [CrossRef] [PubMed]

27. Nan, L.; Feng, Z.; Wei, C.J.; Liang, W.Y.; Zhang, N.; Wang, C.M.; Li, Q.Z.; Gao, X.J. Function of SREBP1 in the milk fat synthesis of dairy cow mammary epithelial cells. Int. J. Mol. Sci. 2014, 15, 16998-17013.

28. Duchemin, S.; Bovenhuis, H.; Stoop, W.M.; Bouwman, A.C.; van Arendonk, J.A.; Visker, M.H. Genetic correlation between composition of bovine milk fat in winter and summer, and DGAT1 and SCD1 by season interactions. J. Dairy Sci. 2013, 96, 592-604. [CrossRef]

29. Shi, B.; Jiang, Y.; Chen, Y.; Zhao, Z.; Zhou, H.; Luo, Y.; Hu, J.; Hickford, J.G.H. Share Variation in the Fatty Acid Synthase Gene (FASN) and Its Association with Milk Traits in Gannan Yaks. Animals 2019, 9, 613. [CrossRef]

30. Jiao, B.L.; Zhang, X.L.; Wang, S.H.; Wang, L.X.; Luo, Z.X.; Zhao, H.B.; Khatib, H.; Wang, X. MicroRNA-221 regulates proliferation of bovine mammary gland epithelial cells by targeting the STAT5a and IRS1 genes. J. Dairy Sci. 2019, 102, 426-435. [CrossRef]

31. Chhabra, R.; Dubey, R.; Saini, N. Cooperative and individualistic functions of the microRNAs in the miR-23a 27a 24-2 cluster and its implication in human diseases. Mol. Cancer 2010, 9, 232. [CrossRef]

32. Chen, L.; Hou, J.; Ye, L.; Chen, Y.; Cui, J.; Tian, W.; Li, C.; Liu, L. MicroRNA-143 regulates adipogenesis by modulating the MAP2K5-ERK5 signaling. Sci. Rep. 2014, 4, 3819. [CrossRef] [PubMed] 
33. Kim, Y.; Min, T.S.; Seo, K.; Kim, S.H. Expression of pref-1/dlk-1 is regulated by microRNA-143 in 3T3-L1 cells. Mol. Biol. Rep. 2015, 42, 617-624. [CrossRef]

34. Zhao, Y.; Liu, X.; Lu, Y.X. MicroRNA-143 regulates the proliferation and apoptosis of cervical cancer cells by targeting HIF-1 $\alpha$. Eur. Rev. Med. Pharmacol. Sci. 2017, 21, 5580-5586. [PubMed]

35. Nan, L.; Yong, Y.; He, K.G.; Zhang, F.Y.; Zhao, L.B.; Zhou, W.; Yuan, J.H.; Liang, W.; Fang, X.H. Single-Molecule Imaging Reveals the Activation Dynamics of Intracellular Protein Smad3 on Cell Membrane. Sci. Rep. 2016, 6,33469 .

36. Yadav, H.; Quijano, C.; Kamaraju, A.K.; Gavrilova, O.; Malek, R.; Chen, W.; Zerfas, P.; Zhigang, D.; Wright, E.C.; Stuelten, C.; et al. Protection from obesity and diabetes by blockade of TGF- $\beta /$ Smad3 signaling. Cell Metab. 2011, 14, 67-79. [CrossRef] [PubMed]

37. Choy, L.; Derynck, R. Transforming Growth Factor- $\beta$ Inhibits Adipocyte Differentiation by Smad 3 Interacting with CCAAT/Enhancer-binding Protein (C/EBP) and Repressing C/EBP Transactivation Function. J. Biol. Chem. 2003, 278, 9609-9619. [CrossRef]

38. Feng, X.H.; Derynck, R. Specificity and versatility in TGF-signaling through Smads. Annu. Rev. Cell Dev. Biol. 2005, 21, 659-693. [CrossRef]

39. Zhu, Q.; Chang, A.; Xu, A.; Luo, K. The regulatory protein SnoN antagonizes activin/Smad2 protein signaling and thereby promotes adipocyte differentiation and obesity in mice. J. Biol. Chem. 2018, 293, 14100-14111. [CrossRef]

(C) 2020 by the authors. Licensee MDPI, Basel, Switzerland. This article is an open access article distributed under the terms and conditions of the Creative Commons Attribution (CC BY) license (http://creativecommons.org/licenses/by/4.0/). 